\title{
THE USE OF A MODULAR TITANIUM ENDOPROSTHESIS IN SKELETAL RECONSTRUCTIONS AFTER BONE TUMOR RESECTIONS: METHOD PRESENTATION AND ANALYSIS OF 37 CASES
}

\author{
Alberto Tesconi Croci, Olavo Pires de Camargo, André Mathias Baptista and \\ Marcelo Tadeu Caiero
}

RHCFAP/3020

CROCI AT et al. - The use of modular titanium endoprosthesis in skeletal reconstructions after bone tumor resections: method presentation and analysis of 37 cases. Rev. Hosp. Clín. Fac. Med. S. Paulo 55(5):169-176, 2000.

We analyzed 37 patients who underwent segmental wide resection of bone tumors and reconstruction with a modular titanium endoprosthesis at the Orthopaedic Oncology Group, between 1992 and 1998. Twelve patients were male and 25 were female, with a mean age of 30 years $(9-81)$. The mean follow-up was 14 months $(2-48)$. The diagnoses were: osteosarcoma (14 cases), metastatic carcinoma (10), Ewing's sarcoma (4), giant cell tumor (4), malignant fibrous histiocytoma (3), chondrosarcoma (1), and aneurysmal bone cyst (1). Eleven articulated total knee, 8 partial proximal femur with bipolar acetabulum, 8 partial proximal humerus, 3 total femur, 2 partial proximal tibia, 2 diaphyseal femur, 2 diaphyseal humerus, and 1 total proximal femur with cementless acetabulum endoprosthesis implant procedures were done. The complications related to the procedure included: infection (5 cases), dislocation (3), module loosening (1), and ulnar nerve paresthesia (1). We used the following criteria for the clinical evaluation: presence of pain, range of motion, reconstruction stability, surgical and oncologic complications, and patient acceptance. The results were good in $56.8 \%$ of the cases, regular in $32.4 \%$ and poor in $10.8 \%$.

DESCRIPTORS: Endoprosthesis. Bone tumors. Surgical treatment. Bone neoplasms.

Nowadays in the orthopaedic field, there is much discussion about skeletal reconstructions in cases where the bone losses, particularly at the articular surface, are sufficient to prevent the use of conventional prosthesis.

Replacements since 1912 involving filling the space after segmental resections with bone transplants have been studied by PUTTI.

A landmark in the literature is the paper by DELITALA (1947) ${ }^{7}$, which presented the first results with the use of endoprostheses after segmental resections, followed by a paper in 1956 in which the kind of material used was described.
In our country, CAMARGO $(1967)^{1}$ reported on segmental resection of bone tumors and surgical skeletal reconstruction in 81 patients, 51 of whom underwent replacements with endoprosthesis.

There has been a clear evolution in the materials since then, associated with improvements in surgical techniques. Despite these developments, the clinical results obtained with replacements after segmental resections

From the Department of Orthopaedics, Hospital das Clínicas, Faculty of Medicine, University of São Paulo. have still had much to improve in the ensuing years.

Improved implants are needed in two orthopaedic sub-specialties: in revision arthroplasties, especially of the hip, and in replacements after segmental resections of bone tumors.

Since there are still many problems concerning the use of homologous bone grafts, including difficulties with donators' families, material handling, and high infrastructure costs, a relatively high number of endoprosthesis have been used in our country.

It should be stressed that in the orthopaedic oncology field, neoadjuvant chemotherapy for malignant tumors 
has tremendously increased the survival for these patients. Consequently, problems have arisen related to the longer follow-up of the endoprosthesis, such as breaking and loosening of the implants, which were observed earlier with conventional prostheses (total hip and total knee prostheses).

Therefore, a greater number of revision procedures have been done. The physicians who perform these operations are familiar with the difficulties found intraoperatively, including severe bone loss after removal of the implant and the cement.

With the objective of making these revision procedures easier, we designed a modular endoprosthesis system. Its simplicity allows the surgeon to create customized implants by combining modular elements, thereby avoiding the waiting time for conventional custommade endoprostheses, resulting in diminished hospitalization time and cost, which in our country is a factor to be considered.

We present an analysis of 37 patients who underwent segmental resections followed by replacement with the modular titanium endoprosthesis between 1992 and 1998.

\section{PATIENTS}

Thirty-seven patients ( 25 females and 12 males) underwent segmental resection and replacement with a modular titanium endoprosthesis between 1992 and 1998.

Patient ages ranged from 9 to 81 years, with a mean age of 30.05 years. All diagnoses were confirmed by bone biopsy prior to surgery and are presented in Table 1.

Regarding the anatomic location of the neoplastic lesions, 4 patients had tumors in more than one site. Three patients had osteoblastic osteosarcoma-one had lesions in the distal femur and proximal tibia, one had 3 le-
Table 1 - Cases according to histologic diagnosis.

\begin{tabular}{lll}
\hline Diagnosis & Number of cases & \% \\
\hline Osteoblastic osteosarcoma & 14 & 37.84 \\
Metastatic carcinoma & 10 & 27.03 \\
Ewing's sarcoma & 4 & 10.81 \\
Giant cell tumor & 4 & 10.81 \\
Malignant fibrous histiocytoma & 3 & 8.11 \\
Chondrosarcoma & 1 & 2.70 \\
Aneurysmal bone cyst & 1 & 2.70 \\
\hline TOTAL & $\mathbf{3 7}$ & $\mathbf{1 0 0 . 0 0}$ \\
\hline
\end{tabular}

Table 2 - Cases according to type of endoprosthesis.

\begin{tabular}{lll}
\hline Type of endoprosthesis & Number of cases & \% \\
\hline Articulated total knee & 11 & 29.73 \\
Partial bipolar proximal femur & 8 & 21.62 \\
Partial proximal humerus & 8 & 21.62 \\
Total femur & 3 & 8.10 \\
Partial proximal tibia & 2 & 5.41 \\
Diaphyseal femur & 2 & 5.41 \\
Diaphyseal humerus & 2 & 5.41 \\
Total hip proximal femur & 1 & 2.70 \\
\hline TOTAL & $\mathbf{3 7}$ & $\mathbf{1 0 0 . 0 0}$ \\
\hline
\end{tabular}

sions in the same femur, and one had 2 lesions in the same femur. The fourth patient had metastatic carcinoma in the proximal, diaphyseal, and distal femur. Therefore, there were 44 distinct anatomic sites involved in the 37 patients (Fig. 1).

The follow-up ranged from 2 to 48 months, with a mean follow-up of 14.84 months.

The distribution of the cases according to the type of endoprosthesis employed is in Table 2.

\section{SURGICAL TECHNIQUE}

The surgical approach varied according to the site of the lesion and followed these principles: A) Skin and subcutaneous tissue incision including the biopsy scar, deepening to the tumor itself, although not exposing it. B) Hemostasis with hemostats and cautery. C) Fascia incision and muscle blunt dissection; there should be constant irrigation

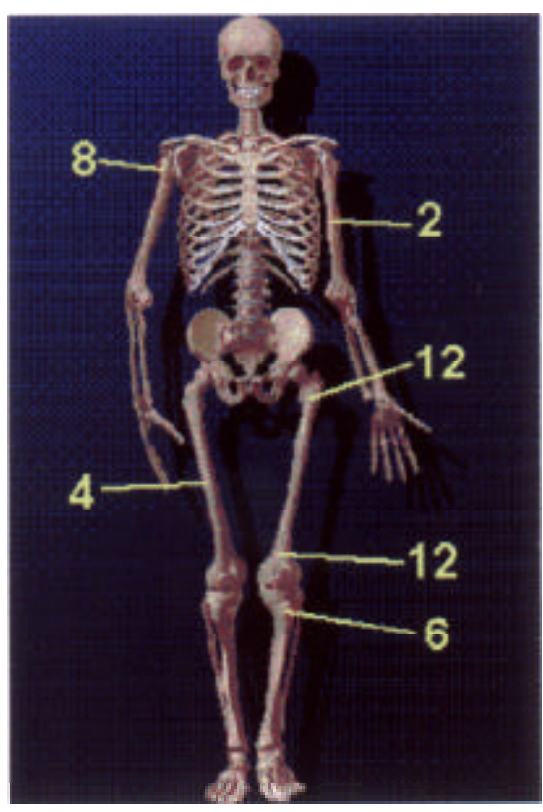

Figure 1 - Lesions according to anatomic location.

and aspiration of the surgical field with saline solution in order to better visualize the muscular compartments. 


\section{WIDE RESECTION}

The dissection was always performed in normal tissue, avoiding any contact with the tumor, allowing proximal and distal safety margins of at least $1 \mathrm{~cm}$ around it. Adhesions between surgical compartments were not removed, because they may indicate tumor compromise. The neurovascular bundle was identified in its full extent and maintained under a Penrose drain.

Tissue adhering to the tumor was resected along with it, maintaining the safety margin all around the lesion. Resection through the tumor pseudocapsule was avoided. The dissection was always through normal muscle.

The osseous approach was made proximally and distally to the tumor, always with a safety margin of at least $2 \mathrm{~cm}$. The surgical field was protected with sponges, and the osteotomies were carried out with an oscillating saw, always through normal bone. If necessary, an osteotome was used to finish the osteotomy. The resected tumor was removed from the surgical field surrounded by normal tissue.

\section{RECONSTRUCTION}

After the wide resection, the limb reconstruction depended on the anatomic site of the tumor and used the endoprosthesis that will be described below.

\section{MODULAR ENDOPROSTHESIS}

The modular endoprosthesis system is composed of a simple set of instruments that allow a series of component combinations, and was designed for a wide variety of reconstructions. We briefly present its components.

\section{BASIC SET OF INSTRUMENTS}

The basic set of instruments for the modular endoprosthesis can be seen in figures 2,3 , and 4 .

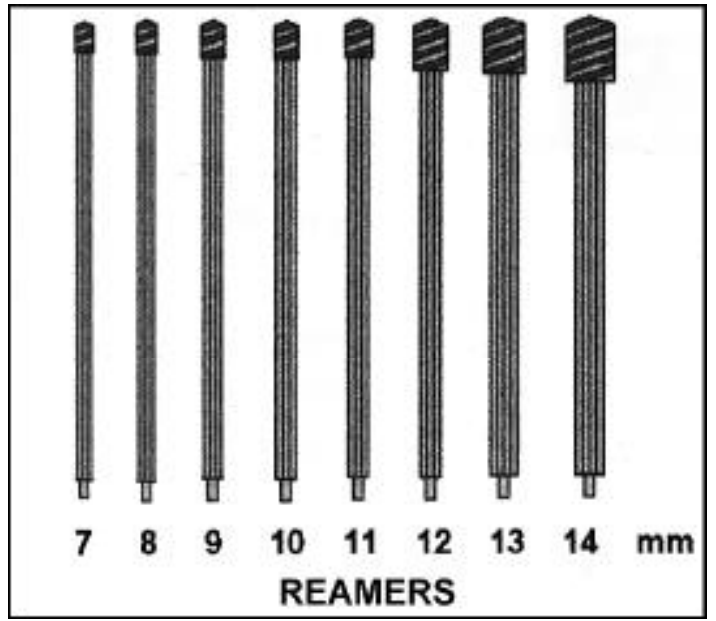

Figure 2 - Flexible reamers for preparing the medullary canal.

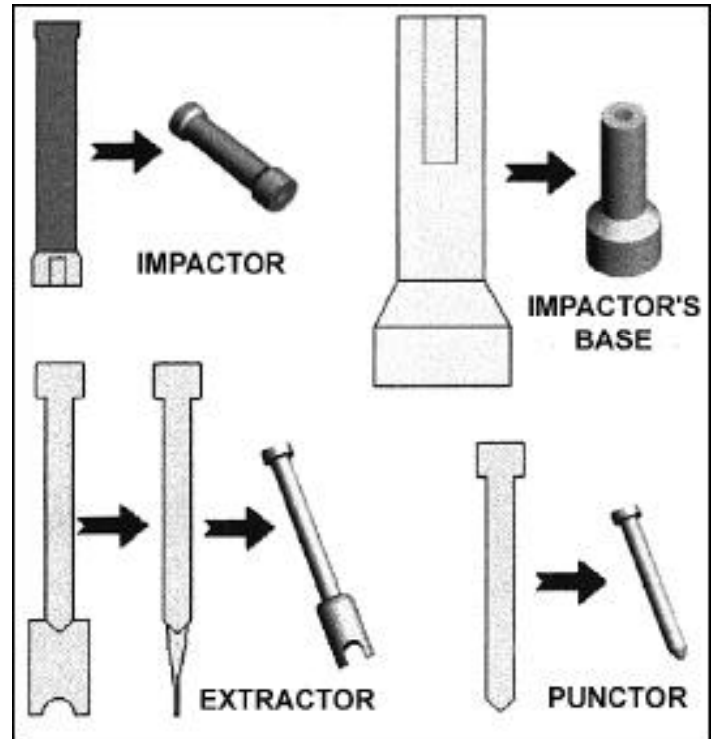

Figure 3 - Basic set of instruments (impactor, impactor's base, extractor, and punctor).

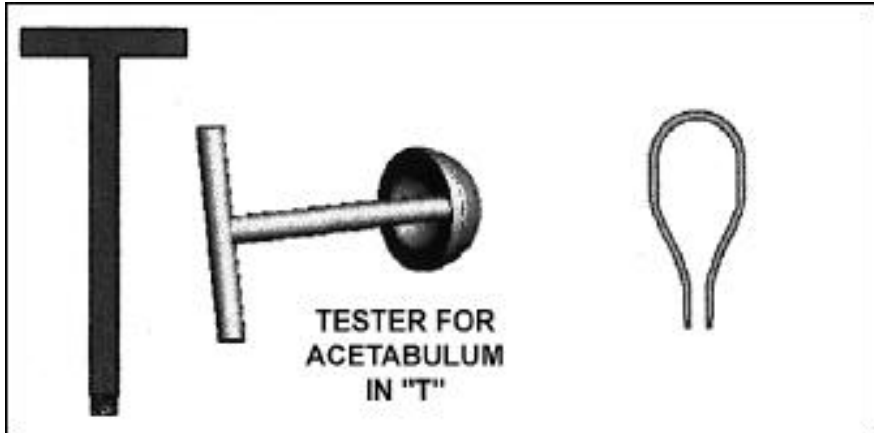

Figure 4 - Basic set of instruments (acetabulum tester and acetabular augmentation clamp).

\section{MODULES}

The modules are divided into the diaphyseal base (Fig. 5), interme- diate module (Fig. 6), diaphyseal module (Fig. 7), trochanteric module (Fig. 8 ), and proximal humerus module (Fig. 9). 

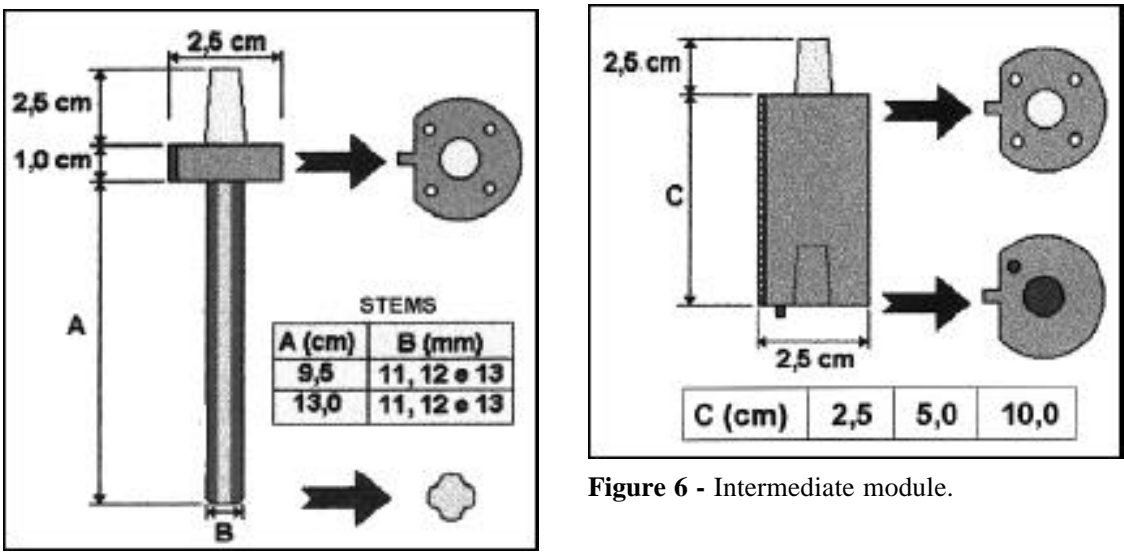

Figure 6 - Intermediate module.

Figure 5 - Diaphyseal base.

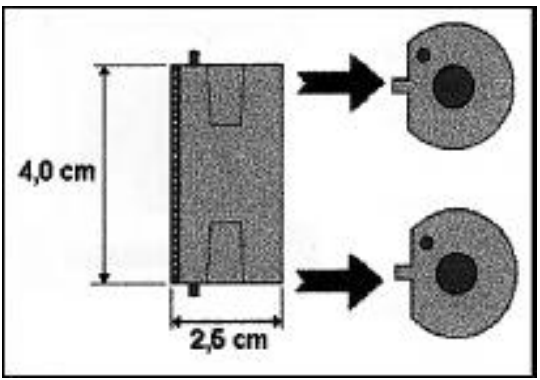

Figure 7 - Diaphyseal module.

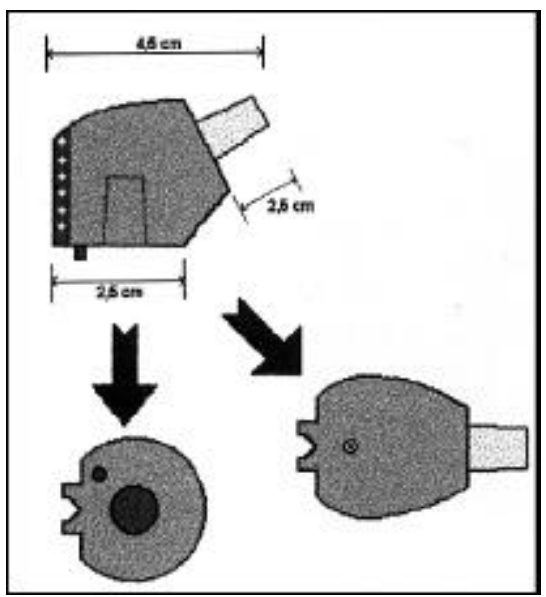

Figure 9 - Proximal humerus module.

\section{SPECIAL MODULES}

The special modules, partial or total, are those used in the articular reconstructions. They are composed of the test bipolar femoral heads (Fig. 10), implant bipolar femoral heads (Fig. 11), partial humeral heads (Fig. 12), articulated total knee endoprosthesis (Fig. 13), and partial proximal tibia endoprosthesis (Fig. 14).

\section{ARTICULATED TOTAL KNEE (DIS-} TAL FEMUR) ENDOPROSTHESIS

The total knee endoprosthesis is of the articulated type, with a body of titanium attached to titanium cylindrical pieces and to the intramedullary stem of 11,12 , or $13 \mathrm{~mm}$ diameter with a metal-polyethylene articulation (Fig. 15). It is measured according to the amount of bone to be resected as determined in the preoperative studies.

\section{PARTIAL PROXIMAL HUMERUS ENDOPROSTHESIS}

The partial proximal humerus modular titanium endoprosthesis is attached by a conic fitting to small cylindrical pieces measuring 2.5 and 5.0 $\mathrm{cm}$ in length, allowing the length of the endoprosthesis to equal the length of the segment resected. The head is made of stainless steel, and the intramedullary stem is 8,9 , or $10 \mathrm{~mm}$ in diameter (Fig. 16).

\section{PARTIAL PROXIMAL FEMUR ENDOPROSTHESIS}

The partial proximal femur endoprosthesis used was of the bipolar type. Its modular body is made of titanium of the same type described previously. Its intramedullary stem is 11,12 , or $13 \mathrm{~mm}$ in diameter. Its bipolar head is made of stainless steel with a diameter ranging from 36 to 50 $\mathrm{mm}$ in its external surface, and polyethylene in its internal surface. The bipolar head articulates with a second head of 22 or $28 \mathrm{~mm}$ diameter that is attached to the endoprosthesis body by a conic fitting (Fig.17). In order to obtain better articular stability, a polyethylene ring is positioned around the 


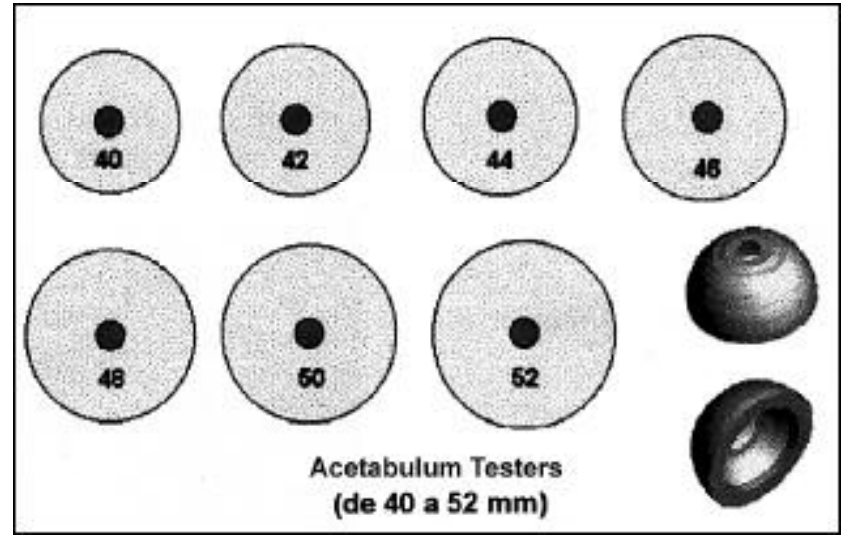

Figure 10 - Test bipolar femoral heads.

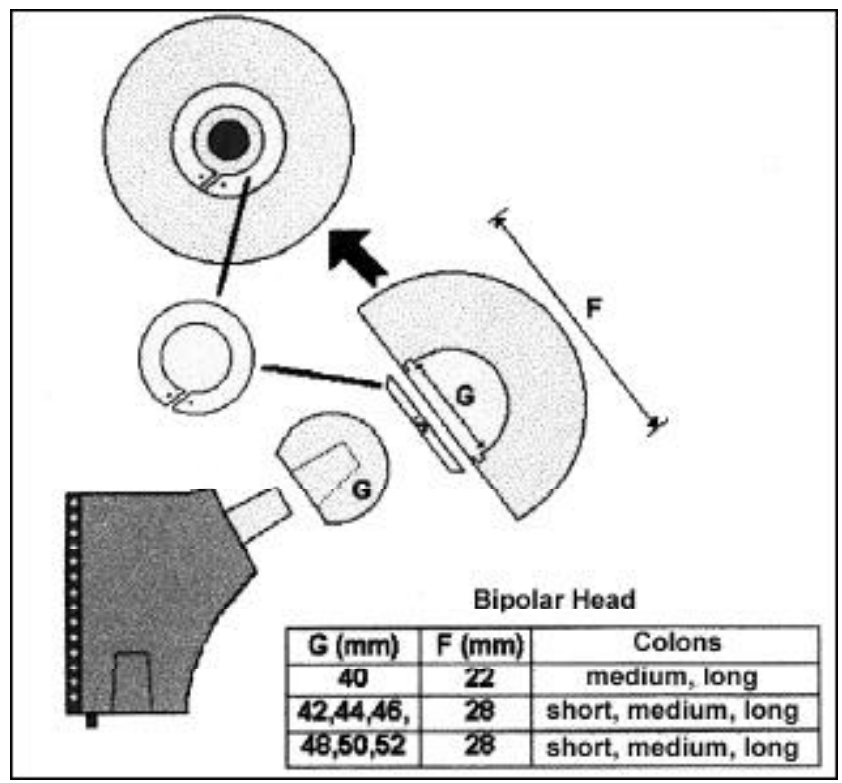

Figure 11 - Implant bipolar femoral heads.

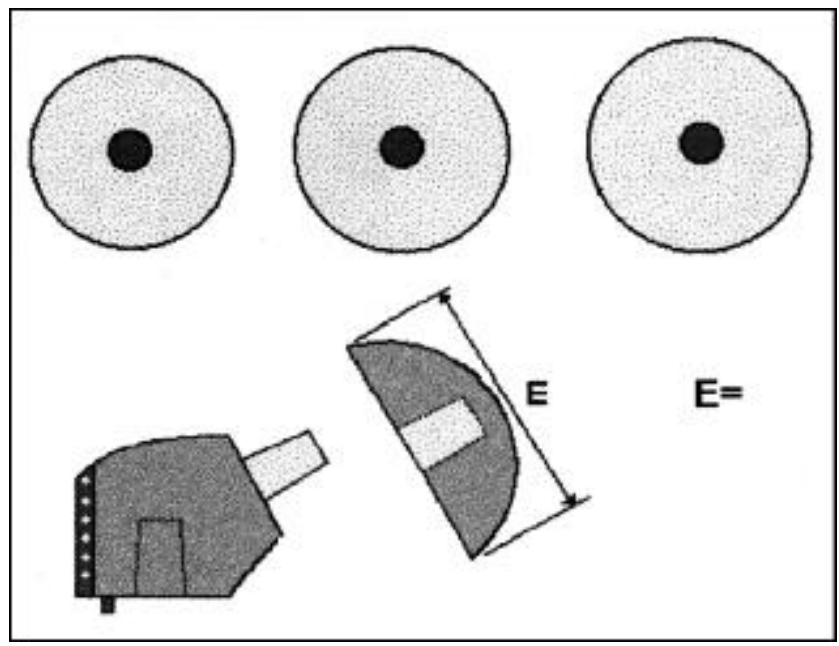

Figure 12 - Partial humeral heads.

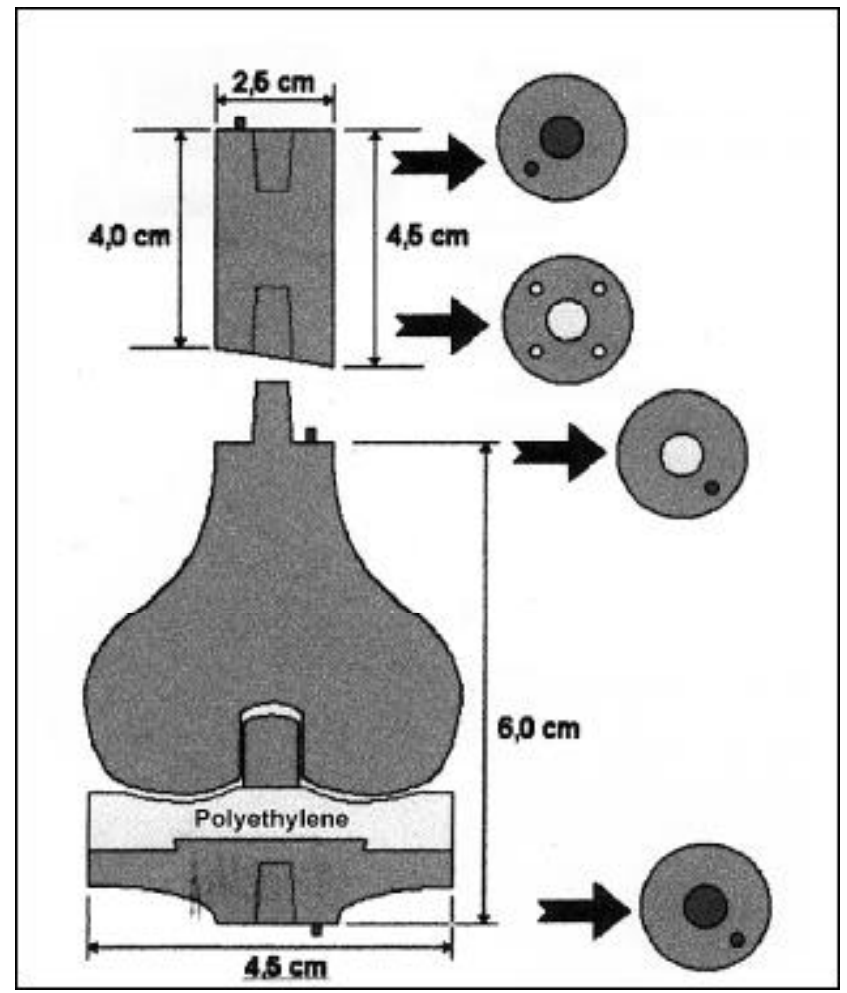

Figure 13 - Articulated total knee endoprosthesis.

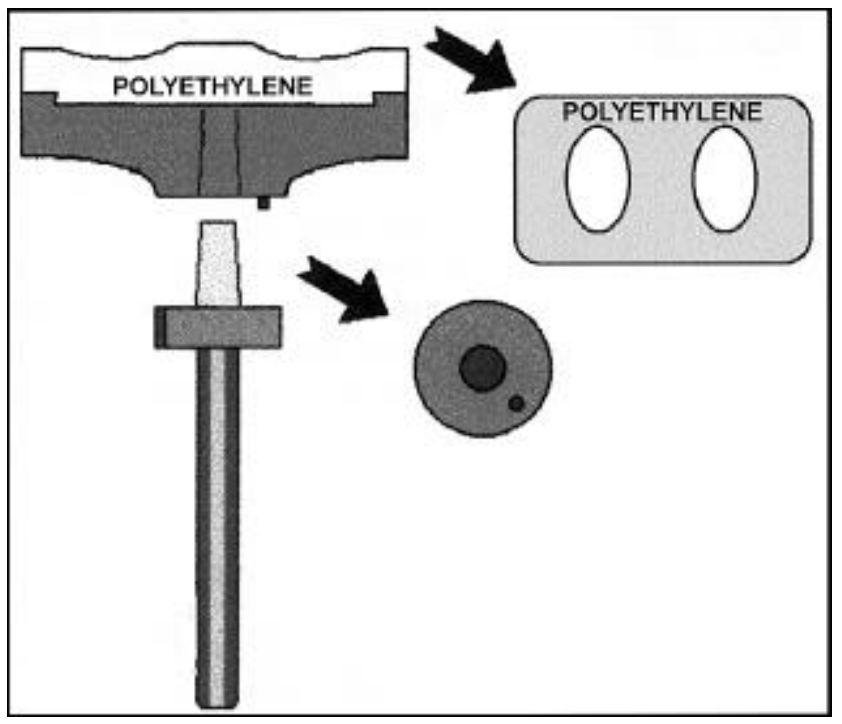

Figure 14 - Partial proximal tibia endoprosthesis. 


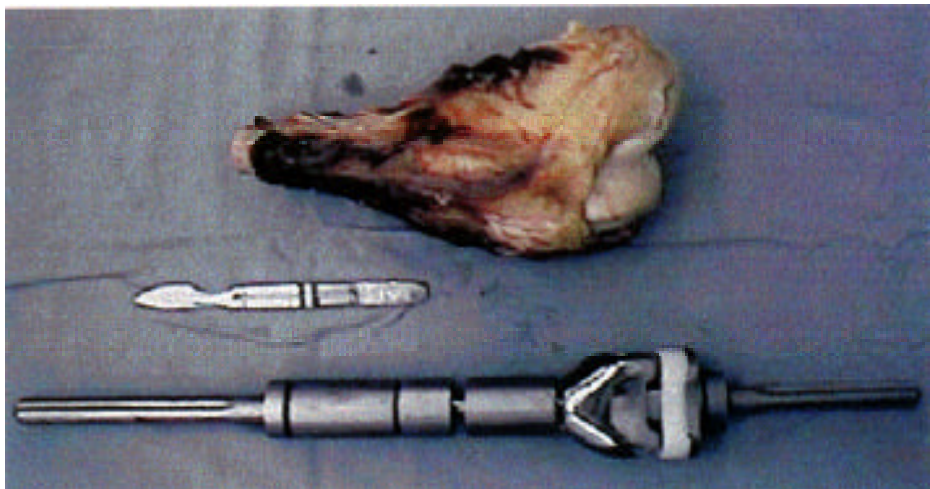

Figure 15 - Resected distal femur osteosarcoma and the articulated total knee endoprosthesis.

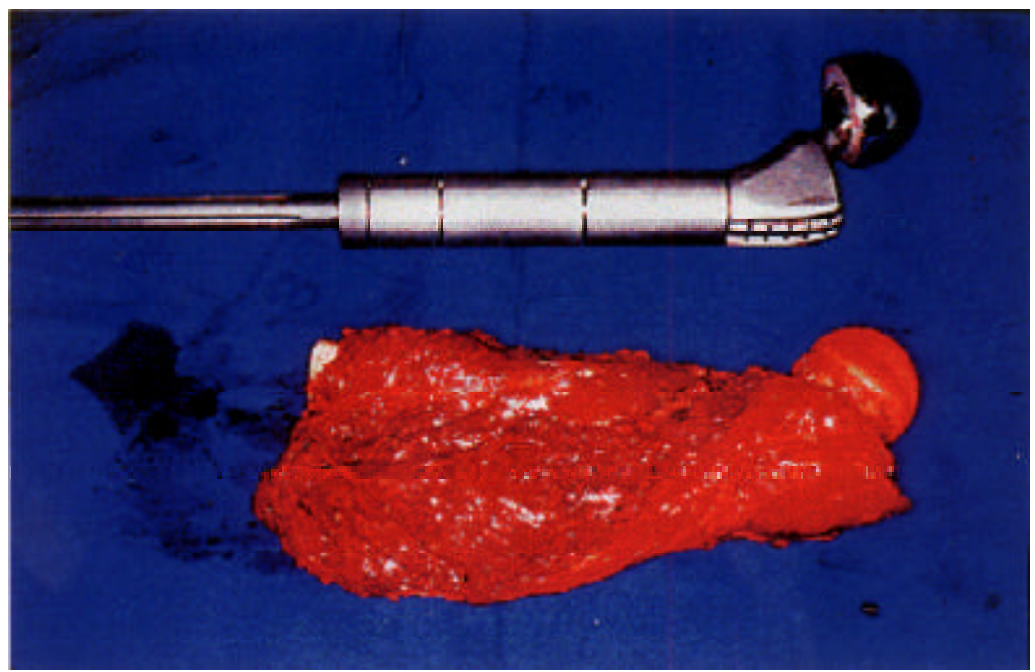

Figure 17 - Partial proximal femur endoprosthesis and proximal femur after wide resection.

neck of the prosthesis that is fitted internally in the bipolar head.

\section{PARTIAL PROXIMAL TIBIA ENDOPROSTHESIS}

The proximal tibia endoprosthesis used was of the partial type; its titanium body has an intramedullary stem of 8 , 9 , or $10 \mathrm{~mm}$ diameter. Its proximal portion, which articulates directly with the distal femur articular surface, is made of polyethylene according to the anatomic shape of the patient's distal femur.

\section{TOTAL FEMUR ENDOPROSTHESIS}

The total femur endoprosthesis used was partial for the hip and total for the knee. Its body is made of titanium and is modular, with cylindrical pieces of 5 or $10 \mathrm{~cm}$ in length attached by a conic fitting. The femoral head is of the bipolar type, as described for the proximal femur endoprosthesis. The distal portion is made of titanium, using a total articulated knee in the same fashion as for the distal femur endoprosthesis (total knee).

\section{FEMORAL AND HUMERAL DIAPHY- SEAL ENDOPROSTHESIS}

The femoral and humeral diaphyseal endoprosthesis is made of 2 cylindrical titanium pieces with intramedullary stems of 8,9 , or $10 \mathrm{~mm}$ diameter for the humerus and 11,12 , or $13 \mathrm{~mm}$ diameter for the femur, attached to a diaphyseal module with a conic fitting, with the necessary intermediate modules of the same material between them.

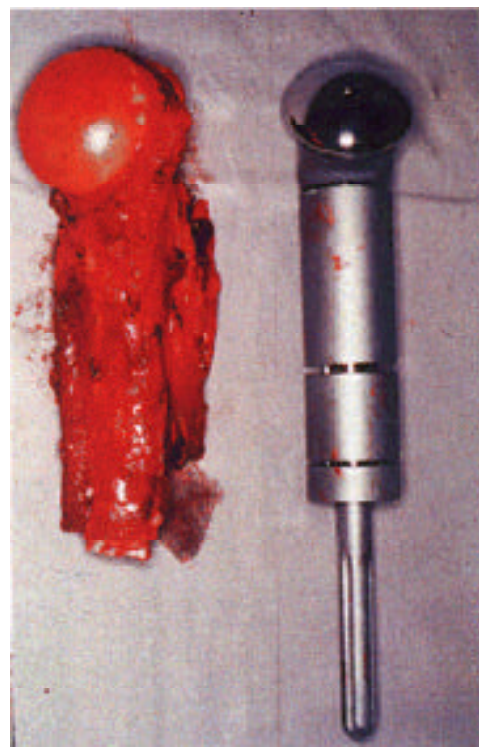

Figure 16 - Titanium partial proximal humerus endoprosthesis and proximal humerus after wide resection.

\section{EVALUATION CRITERIA}

For the results analysis, we used oncologic criteria based on the tumor recurrence, as well as clinical criteria based on presence of pain, limb function, articular range of motion of the limb, infection, and patient acceptance.

The results were considered:

\section{GOOD}

- No local recurrence.

- No spontaneous pain to palpation and motion.

- Functional limb, with variable degree of range of motion.

- No persistent local infection.

- Good patient acceptance.

\section{REGULAR}

- No local recurrence.

- Mild or moderate pain with motion.

- Partially functional limb, with partial range of motion limitation.

- No persistent local infection.

- Regular patient acceptance.

\section{POOR}

- Unresectable local recurrence.

- Intense pain, spontaneous or in motion.

- Great articular instability, restrain- 
ing gait.

- Deep local infection, uncontrolled, even after surgical debridement.

- Bad patient acceptance.

\section{RESULTS AND COMPLICATIONS}

According to the evaluation criteria, the results were good in 21 patients $(56.8 \%)$, regular in $12(32.4 \%)$, and poor in $4(10.8 \%)$.

Regarding complications, 5 patients developed infection, with 2 deep infections associated with dehiscence, and 3 with superficial infections, all due to Staphylococcus aureus. All underwent surgical debridement and specific intravenous therapy with antibiotics, 3 of them with good results and 2 with poor results. Three patients with dislocation of the proximal femur endoprosthesis underwent closed reduction under anesthesia, all with good results. One of the patients with persistent infection also presented with a module loosening; the case was already considered a poor result. Another patient presented with an intermediate module loosening, requiring a revision procedure for component exchange, with a good result. Finally, one patient developed ulnar nerve paresthesia, credited to the surgical manipulation, but had full recovery afterwards.

Two other patients developed local recurrence (both osteosarcoma) and underwent radical surgery, these cases thus being considered poor results.

\section{DISCUSSION}

Skeletal reconstructions with endoprostheses after wide resection for bone tumors have been performed for more than a century. Reconstructions were initially used in low-grade malignant and metastatic lesions.

As chemotherapy progressed, mainly in primary malignant bone tumors such as osteosarcoma and Ewing's sarcoma, there has been a considerable response in terms of tumor volume in a great percentage of the cases, thus making limb salvage procedures feasible in over $50 \%$ of the cases.

Additionally, the longer survival of these patients has presented orthopedic surgeons with several orthopedic problems inherent to the materials used in the implants, such as breakage and loosening of the implant, which were less frequently observed previously due to the unsuccessful oncologic treatment $^{6,8,9,10}$.

Increasing numbers of revision procedures have been made in large orthopedic centers, thereby increasing the number of complications, primarily infections. In response, simpler and longer lasting implants have been developed that allow the partial exchange of the implant in case of a revision procedure.

The modular endoprosthesis systems used by several authors $2,3,5,6,8,9,10$ since 1985 have the advantage of allowing immediate surgery, without the delay required for custom-made endoprostheses. Additionally, use of modular systems circumvents the problem of mistaken measurements for custom-made implants, which leads to improvisations resulting in more extensive resections, longer surgeries, and more intra- and postoperative complications. Modular endoprothesis sys- tems allow the surgeon to quickly and precisely adjust the endoprosthesis, independently of the extent of the resection, allowing for intraoperative changes in the surgical plan. The endoprosthesis is assembled inside the surgical suite, and additionally is lower in cost.

Another advantage of the modular systems is the possibility of expanding the endoprosthesis in skeletally immature patients in order to equalize the limbs when the patient reaches skeletal maturity. It is possible to attach intermediate modules between the modules already in the endoprosthesis in a minor surgical procedure.

The modular system that we developed $^{3}$ will certainly go through several modifications as more replacements are performed and more complications from longer follow-up occur. The complications reported, such as dislocation of the proximal femur endoprosthesis and infection, occur in the same incidence as with the custom-made endoprosthesis 5 .

We tried to design a simple modular system characterized by easy application and based on the non-modular endoprostheses, such as the bipolar femoral head (Fig. 17), and with a fitting system similar to that of the articulated Guepar endoprosthesis ${ }^{5,8}$.

The other modular endoprosthesis, such as the proximal humerus, partial proximal tibia, and diaphyseal endoprosthesis followed the nonmodular endoprosthesis characteristics as well: they were made of titanium, with the articular modules made of polyethylene and titanium (Figs. 15 and 16). 
CROCI AT e col. - O emprego da endoprótese modular de titânio na reconstrução esquelética após ressecção de tumores ósseos. Apresentação do método e análise de 37 pacientes operados. Rev. Hosp. Clín. Fac. Med. S. Paulo 55 (5):169-176, 2000.

Os autores analisaram 37 pacientes operados de 1992 a 1998 no Grupo de Oncologia Ortopédica, em que foi utilizada a endoprótese modular de titânio na reconstrução esquelética, após a ressecção segmentar de tumores ósseos. Doze pacientes foram do sexo masculino e 25 do sexo feminino, sendo que a idade variou de 9 a 81 anos, com média de 30 anos. O tempo de seguimento variou de dois a 48 meses, com média de 14 meses. Com relação ao diagnóstico pré-operatório, este foi confirmado pela biópsia em todos os casos e teve a seguinte distribuição: osteossarcoma osteoblástico (14 casos), carcinoma metastático (10), sarcoma de Ewing (4), tumor de células gigantes (4), fibrohistiocitoma maligno (3), condrossarcoma (1) e cisto ósseo aneurismático (1). Nestes foram realizadas onze endopróteses de joelho articulado (total), oito de fêmur proximal com quadril parcial bipolar, oito de úmero proximal parcial, três de fêmur total, duas parciais proximais da tíbia, duas diafisárias de fêmur, duas diafisárias de úmero, e uma proximal do fêmur com quadril total e componente acetabular sem cimento. As complicações relacionadas ao uso da endoprótese foram: infecção (5 casos), luxação (3), soltura de módulo (1) e parestesia do nervo ulnar (1). Utilizamos como critérios clínicos a presença de dor, a mobilidade articular, a estabilidade da reconstrução, as complicações cirúrgicas e oncológicas e a aceitação do paciente. Obtivemos $56,8 \%$ de bons resultados, $32,4 \%$ de regulares e $10,8 \%$ de maus.

DESCRITORES: Endopróteses. Tumores ósseos. Tratamento cirúrgico. Neoplasias ósseas.

\section{REFERENCES}

1. CAMARGO FP - Ressecção segmental em tumores ósseos e reconstrução cirúrgica do esqueleto : estudo baseado em 81 casos. São Paulo, 1967. (Tese - Faculdade de Medicina, Universidade de São Paulo).

2. CAMARGO OP, OLIVEIRA NRB, CAMPOS FILHO et al. Polyethylene endoprosthesis for the treatment of malignant bone tumors: a long term follow up study. In: LANGLAIS B (ed.): Limb salvage major reconstruction in oncologic conditions. Berlin, Heidelberg, Springer, 1991.

3. CAMARGO OP, CROCI AT \& CAMPOS FILHO R - Nova endoprótese diafisária no tratamento das neoplasias ósseas metastáticas. Resultados preliminares. Rev Bras Ortop 1992; 27(11/12): 841-3.

4. CAMARGO OP, CROCI AT \& OLIVEIRA NRB - Partial endoprosthesis of the proximal tibia for high grade malignant sarcomas and aggressive benign tumors : a report of 25 cases (1975 - 1990) with a long-term follow-up. In: LANGLAIS B - Limb Salvage. Berlim. Springer, 1993. p. 121-15. (Current Trends).

5. CAMARGO OP, CROCI AT, CAMPOS FILHO R et al. - O sistema de endoprótese modular na reconstrução após ressecção ampla de neoplasias metastáticas e primárias. Rev Bras Ortop 1995; 30: 815-8.
6. CHAO E \& SIM F - Modular Types of Endoprosthesis for Limb Salvag. In: ENNEKING, W.F.(Ed.) - Limb Salvage In Musculoskeletal Oncology. Philadelphia, Livingstone, 1987. p.198-206.

7. DELITALA F - Costituzione di parti interme del corpo umano. Bologna, Capelli, 1956. (Endoprotesi).

8. JOHNSTON J - A modular prosthetic system for tumor surgeons. In: ENNEKING WF (Ed.) - Limb Salvage In Musculoskeletal Oncology. Philadelphia, Livingstone, 1987. p.234-7.

9. KOTZ R, RITSCHI P, KROPEJ D et al. - Cementless Modular Prosthesis Results and Complications. Chir Organ Mov 1990; 75(Suppl.1): 209-211.

10. MALAWER MM \& MELLER I - Experience with Extracortical Fixation of Large Segmental Prosthesis and Description of a Modular Segmental Replacement System (MSRS). In: LANGLAIS $B$ (Ed.) Limb salvage, major reconstruction in oncologic conditions. Berlin, Heidelberg, 1991.

Received for publication on the 11/09/00 